\title{
Stock Market Crash in Bangladesh: The Moneymaking Psychology of Domestic Investors
}

\author{
Md. Tahidur Rahman ${ }^{1, ~ *, ~ S y e d ~ Z a b i d ~ H o s s a i n ~}{ }^{2}$, Md. Habibullah ${ }^{3}$ \\ ${ }^{1}$ Department of Business Administration, EXIM Bank Agricultural University Bangladesh, Chapainawabganj, Bangladesh \\ ${ }^{2}$ Departments of Accounting and Information Systems, University of Rajshahi, Rajshahi, Bangladesh \\ ${ }^{3}$ Bangladesh Institute of Capital Market, Dhaka, Bangladesh
}

Email address:

towhidais@gmail.com (Md. T. Rahman),syed6205@gmail.com (S. Z. Hossain), habib.bicm@gmail.com (Md. Habibullah)

${ }^{*}$ Corresponding author

\section{To cite this article:}

Md. Tahidur Rahman, Syed Zabid Hossain, Md. Habibullah. Stock Market Crash in Bangladesh: The Moneymaking Psychology of Domestic Investors. American Journal of Theoretical and Applied Business. Vol. 3, No. 3, 2017, pp. 43-53. doi: 10.11648/j.ajtab.20170303.12

Received: July 9, 2017; Accepted: August 23, 2017; Published: September 12, 2017

\begin{abstract}
After the cruel crash in 1996 Bangladesh stock market had started growing from 2006 due to listing of a few profitable government entities and Multinational Companies (MNCs). Together with individual investors nearly all commercial banks involved themselves intensely in stock market. Step by step, the bullish market transformed into a bubble and on December 05, 2010, the Dhaka Stock Exchange General Index (DGEN) reached at the record high of 8918.5, almost 5.6 times higher than December 2006. Concurrently, market capitalization and turnover increased by 11.1 times and 61.7 times respectively. However, when the bubble burst on December 19, 2010 the DGEN witnessed its biggest one day fall of 6.7 percent and since then the market has become bearish with almost no positive movement of stock prices. Against this backdrop, this study identified four moneymaking psychologies of domestic investors specifically greed, envy, speculation, and overconfidence that contributed to the formation of bubble, while four loss-minimizing and capital-protecting psychologies such as panic, frustration, lack of self-confidence, and distrust caused the bubble to burst. The bankers, brokers and manipulators were the biggest gainers, whereas the most unaware and greedy small investors encountered heavy loss. The market will be less volatile, more mature, and sustainable when most of the investors will be conscious about the potential risks and returns and the regulators will play their part sincerely and efficiently.
\end{abstract}

Keywords: Dhaka Stock Exchange, Stock Market Crush and Bubble, Moneymaking Psychology

\section{Introduction}

Stock market bubbles have created considerable interest among different groups, since their bursting lead to upheavals in financial markets and the economy as well. The stock market crash of October 1929 is perhaps the most dramatic example of bubble burst all over the world [10]. Thereafter many significant events such as Recession of 1937-38, Tronics boom of 1959-1962, the Nifty fifty of 1970s, Biotech bubble of 1980s, Brazilian markets crash of 1971 coupled with Energy crisis of 1970s and Latin American debt crisis of 1980 s, the Black Monday crash of October 1987, Japanese asset price bubble from 1986 to 1991 together with Asian financial crisis of 1997, the Dot-com bubble of 2000, the global financial crisis in 2007-08, Dubai debt standstill of 2009, European sovereign debt crisis of 2010, Chinese stock market turbulence of 2015-16, and the United Kingdom European Union membership referendum of 2016 had a significant adverse impact on global economies. All these events have made such dramatic change in the prices of stocks that seems to disregard any explanation [5]. As the probable costs of bubble bursts are substantial, economists and policymakers have begun to revisit what they really know about stock bubbles and whether they can be managed for the greater public interest.

All financial practitioners, irrespective of their experience or level of knowledge, sometime make an erroneous judgment and decision because of bias, confidence, and emotion [27]. Moreover, investors' decisions are often influenced by psychological factors that create systematic 
errors, which may affect the market price of financial assets and cause inefficient placement of resources [12]. Some scholars have proposed behavioral and psychological decision theories to explain abnormal stock market effects such as over-reaction, under-reaction, overconfidence, group behavior, formation of bubbles, and burst of bubbles.

Bangladesh stock market, during its life of six decades, has experienced two brutal crashes- one in 1996 and another during 2010-11. The market, since the cruel crash of 1996, has been viewed with suspicion. Thanks to the listing of few profitable government entities and Multi National Companies (MNCs), along with many initiatives from the Government, the market started growing after 2006. Gradually the bullish market turned into a bubble and on December 05, 2010, the Dhaka Stock Exchange General Index (DGEN) reached to the highest record of 8,918.5, almost 5.6 times higher than December 2006. At the same time, market capitalization and turnover increased by 11.1 times and 61.7 times respectively. However, on December 19,2010, another historical incident happened when DGEN witnessed its biggest one day fall of 6.7 percent. In subsequent two months, the market fall by 40 percent and since then the market has been sluggish with almost no positive movement. The latest crash that has harshly affected about 3.3 million people has, nowadays, become a social, political, and national issue of Bangladesh [8]. Although many initiatives have been taken by the Government and the regulators, almost all the initiatives have miserably failed, as after six years of the crash the market is still bearish in 2017. Rahman and Moazzem [23] found statistically significant relationship between regulatory decisions (such as changing margin loan ratio and face value harmonization) and market volatility. The entire situation raises some serious research questions: What explains Bangladesh's stock market bubble? Why did the bubble burst so violently? Why is the market still sluggish when Bangladesh's GDP has increased significantly?

There are many theories in finance and economics that try to explain the causes behind bubbles and their subsequent bursts. In an effort to isolate the causes behind Bangladesh stock market crash, Choudhury [8] found that speculations through omnibus account, lack of restriction on opening Beneficiary Owner $(\mathrm{B} / \mathrm{O})$ accounts, faulty placement of Initial Public Offerings (IPOs), attitude of banks like general investors, rumor by brokers and dealers, erroneous book building method, and lack of monitoring by regulators, all these created the devastating outcome. In addition, a probe committee report led by Khondoker Ibrahim Khaled tried to find out the causes. The probe committee report identified, more or less, the similar factors as responsible for the bubble burst [16]. However, the development of Bangladesh stock market bubble and its subsequent bursting cannot be fully explained by economic theories such as the capital asset pricing model (CAPM), external and internal economic factors, and regulatory initiatives; rather there must have been some intrinsic characteristics. Yao and Luo [35] in their study suggested three moneymaking psychological factors such as greed, envy, and speculation to explain the stock market bubble in China that increased the Shanghai Stock Exchange (SSE) index five folds. Similarly, they explained the burst of the bubble through three opposite psychological factors such as fear, lack of confidence, and disappointment of investors. They also claimed that those factors were expected to be common to any economy in the world. Being convinced with the proposition, the prime objective of this study is to examine whether the factors are equally responsible for the development of stock market bubble and its subsequent burst in Bangladesh.

The current study is based on the secondary data collected from different printed and online publications of Dhaka Stock Exchange (DSE) and Bangladesh Securities and Exchange Commission (BSEC). Among different types of disclosed data, DSE General Index (DGEN), P/E ratio, and Market capitalization have basically been used. Although the stock market of Bangladesh consists of two stock exchanges namely- Dhaka Stock Exchange (DSE) and Chittagong Stock Exchange (CSE), we have taken into consideration the data disclosed by DSE. It is because DSE is the main and oldest burse in Bangladesh where a large majority of the country's transactions take place. Thus the picture of DSE will sufficiently represent the market condition of Bangladesh. In addition, a large number of existing literature on theories of stock valuation, stock market bubbles and their burst, and behavior on investors have been reviewed to explain the dramatic events occurred in Bangladesh stock market during 2010-11.

Section 2 of this paper discusses the symptoms of stock market bubble; section 3 presents the explanation of behavioral finance behind bubble burst; section 4 focuses on the specific moneymaking psychologies of domestic investors that led to stock market crash in Bangladesh; and the last section 5 provides conclusion and recommendations.

\section{Symptoms of Stock Market Bubbles and the Bangladesh Episode}

It is commonly known to all the parties related to stock market that there are ups and downs in the prices of shares like the prices of any other commodities, such as consumer goods. Yao and Luo [35] state that there are many economic factors, which influence demand and supply of stocks, and ultimately cause price fluctuations. When companies, thanks to good macroeconomic conditions, make more profits and pay more dividends, investors find it profitable to buy more shares. Increase in buy pressure gives rise to increase in prices of shares. On the contrary, during poor macroeconomic conditions, when companies are not in a position to make sufficient profit, and pay no dividend, or pay very small dividend, investors lose their interest of investing in shares, and also influence the existing shareholders to sell of their holdings and force prices to down. Share prices can also fluctuate due to some short-term economic shocks such as changes in interest rates, exchange 
rates, inflation, trade balances, and employment rate [35, 34].

The aggregate price of all companies is usually measured by a market index, which is subject to fluctuation in different times due to different factors. In an efficient market, free flow of information is assumed to exist and all investors share the same information which ultimately reduces market volatility. Since markets are not always efficient and investors cannot share the same information, there exists some degree of speculation and uncertainty. Moreover, due to information asymmetry, investors have to make subjective judgments on the future movement of share prices based on their own analysis and expectations. As a result, the actual movements of share prices and also the market index sometimes become much more volatile than the expectation.

Stock markets can fluctuate rather dramatically but not all the fluctuations are considered market bubbles. Yao and Luo [35] states that market bubbles have some or all of the characteristics such as share prices rise sharply and continuously for a certain period of time; $\mathrm{P} / \mathrm{E}$ ratios of companies become unusually high; share prices decline sharply after peaking; the gap between the peak and the low is unusually large (more than 50 percent); the time lag between the peak and the lowest is short (less than one year); it takes a long time (more than two years) to recover to the previous peak.

Stock market bubbles first produce large gains for early investors that results in large public participation and lifting up of prices to unsustainable levels, which is then followed by an abrupt decline in price leaving many speculators with huge financial losses and bankruptcy [32]. In the past, many bubbles developed and burst all over the world, and in the aftermath of every bust, irrational investors were blamed for the crash. A market bubble, depending on the impact on shareholders and the wider economy, and also the extent of overvaluation of share prices, can be large or small. For example, the Techmark bubble was relatively larger than the NASDAQ bubble, because the difference between the maximum and minimum values of the former was much larger than that of the latter. Similarly, the 2010-11 stock market crash in Bangladesh was more devastating than the crash occurred in the country during 1996.

Another symptom of a market bubble is that when it bursts, the actual market index may go well below the normal range of values. Interestingly, it usually takes more time to recover from a bearish market than to develop a bullish market or a market bubble due to the psychological reaction of investors to gains and losses.

Stock market crashes may also occur due to a short-term financial or economic crisis as occurred in Indonesia, South Korea, and Malaysia during the Asian financial crisis in 1997-98. During that crisis, share prices dropped heavily without experiencing any big boom beforehand. The stock market can recover the trouble quickly when the crisis over. But the burst of a market bubble, on the other hand, does not occur due to a financial crisis rather it occurs due to unjustified valuation of stocks by investors. This section, considering the characteristics of stock market bubble and its subsequent burst outlined by Yao and Luo [35], has examined the intensity of market crash that occurred in Bangladesh during 2010-11.

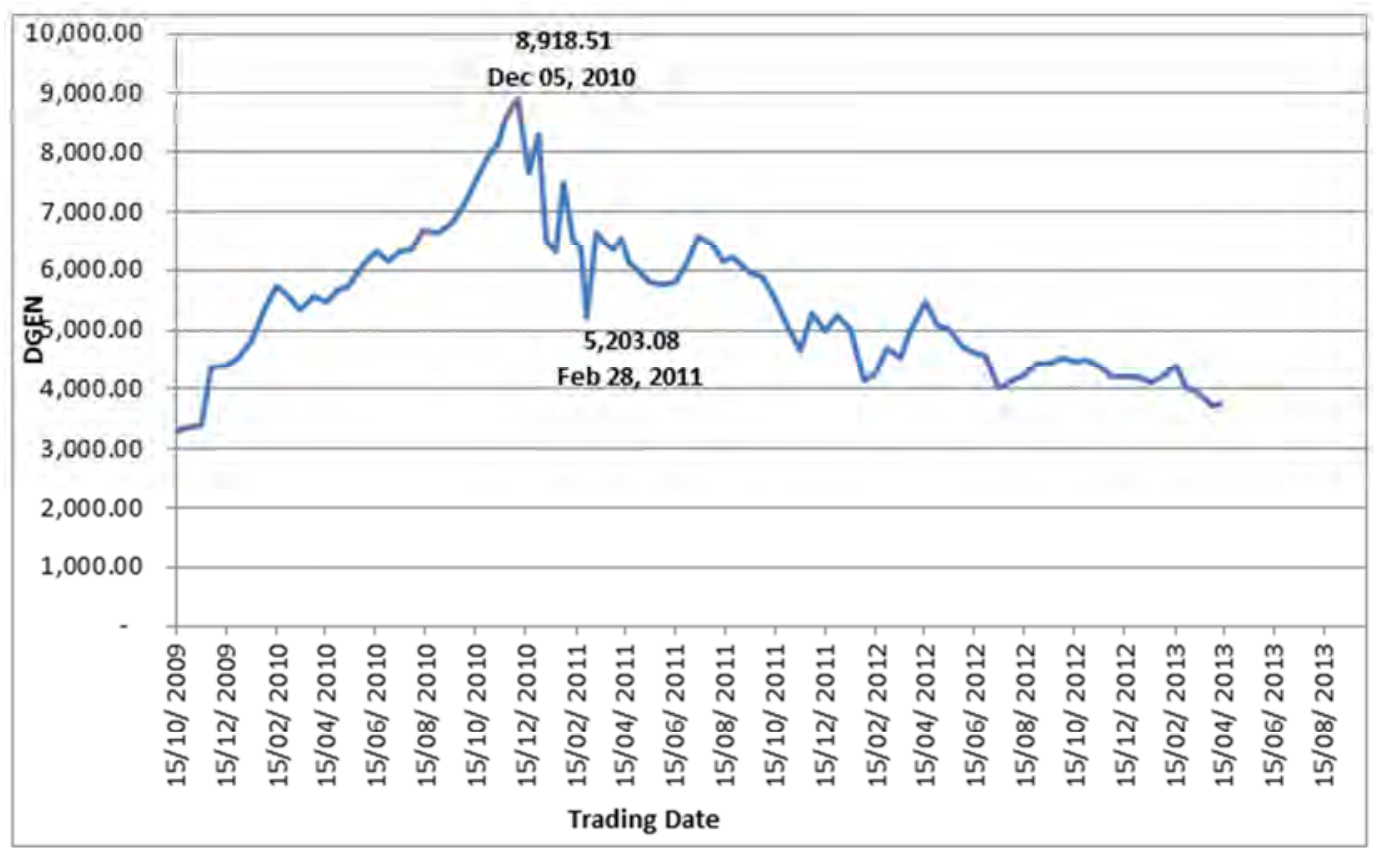

Figure 1. DSE General Index.

It is evident from figure 1 that the bullish market transformed into bubble within a very short period between October 15, 2009 and December 05, 2010. The bubble busted on the subsequent days when the prices of DSE listed stocks fall sharply and consequently, the DGEN decreased by 3,715 point, and reached to 5,203 point from 8,918 point just 3 months back. 


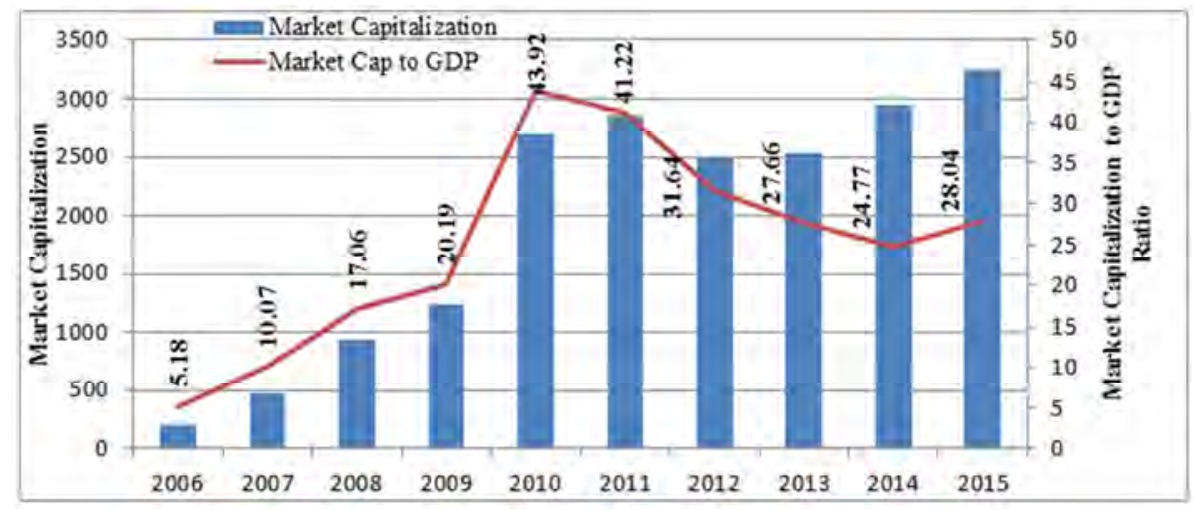

Figure 2. Comparison of Market Capitalization and Market Capitalization to GDP Ratio.

It is evident from figure 2 that the market capitalization to Gross domestic product (GDP) ratio in Bangladesh increased very rapidly and the ratio increased to its highest peak during 2010-11. Although the market capitalization bar showed a slide reduction after the market crash in 2010-11, the bar size would be very little if the market capitalization of many companies that became listed after the crash were excluded.

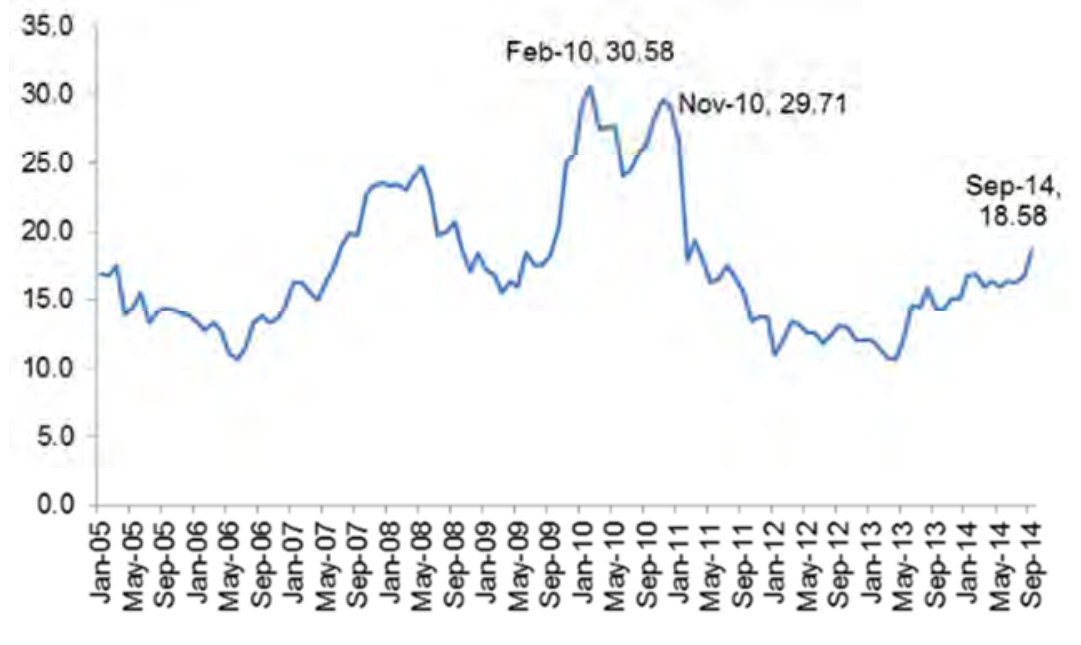

Figure 3. Market P/E Ratios of DSE.

Figure 3 shows that just before the crash, the overall market $\mathrm{P} / \mathrm{E}$ on the DSE was around 30 , which was around 15 one year back in 2009, and around 10 in 2006. Analysts opine that the stocks of a company are investible if its $\mathrm{P} / \mathrm{E}$ ratio is below 15 when an investor can expect above 6.0 per cent dividend along with capital gains. But the average market $\mathrm{P} / \mathrm{E}$ ratio of DSE listed companies reached to around 30 which were two to three times higher than average $\mathrm{P} / \mathrm{E}$ of the same during one to four years back. The highest record of $\mathrm{P} / \mathrm{E}$ was signaling an over-valued market or a stock market bubble in Bangladesh during that period.

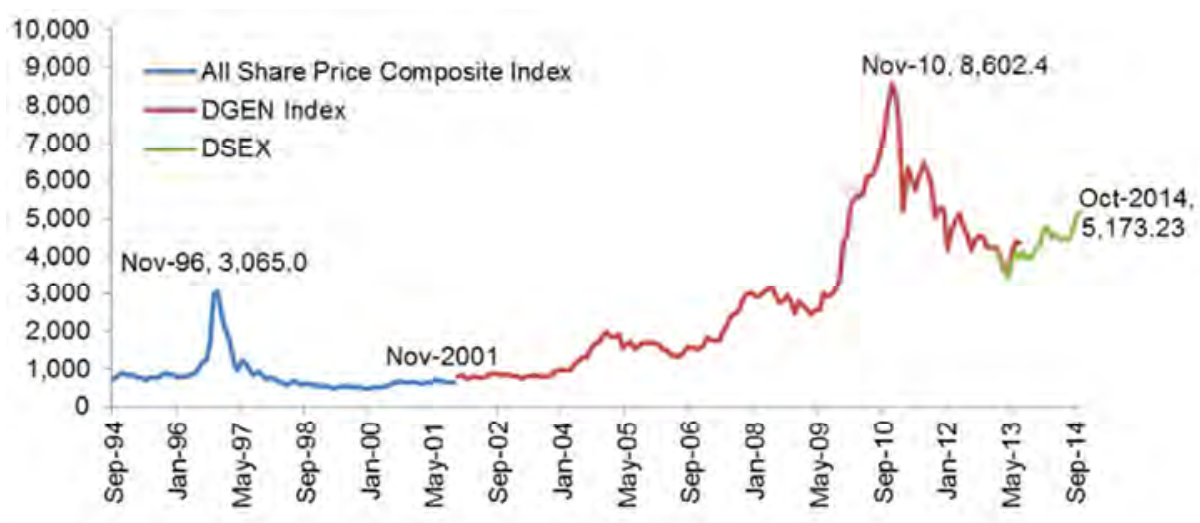

DGEN = DSE General, DSE = Dhaka Stock Exchange, DSEX = DSE Broad Index

Figure 4. Index during Bubble, Crash, and Recovery Period (Source: Asian Development Bank). 
It has been stated earlier from Yao and Luo [35] that it takes a long time (more than two years) to reach the previous peak. However, Bangladesh stock market took around 12 years to reach to its previous peak of 1996. While after the crash during the last month of December 2010 and few subsequent months, six years has already passed but the market is still in bearish position, which indicates that a very deep crash occurred in Bangladesh stock market during 2010-11.

$\mathrm{P} / \mathrm{E}$ ratio is the most popular and simplest technique for stock valuation. The $\mathrm{P} / \mathrm{E}$ ratio, sometimes referred to as the multiple, indicates the dollars amount investors are willing to pay for a dollar of the company's Earnings per share (EPS) [9]. In general, a high $\mathrm{P} / \mathrm{E}$ suggests that investors are expecting higher earnings growth in future. A low $\mathrm{P} / \mathrm{E}$ suggests that the company is currently undervalued or the company is doing exceptionally well as compare to its past trends.

Table 1. Comparison of P/E ratio among Selected Asian Countries.

\begin{tabular}{lllll}
\hline Country & $\mathbf{2 0 1 0}$ & $\mathbf{2 0 1 1}$ & $\mathbf{2 0 1 2}$ & $\mathbf{2 0 1 3}$ \\
\hline Bangladesh & 29.16 & 13.68 & 12.07 & 15.07 \\
India & 19.96 & 19.96 & 16.49 & 16.12 \\
Malaysia & 17 & 17 & 16 & 16 \\
Thailand & 13 & 14 & 13 & 14 \\
Hong Kong & 19 & 18 & 11 & 15 \\
Singapore & 15 & 14 & 11 & 12 \\
\hline
\end{tabular}

Source: BSEC Annual Report

It is evident from Table-1 that the market $\mathrm{P} / \mathrm{E}$ ratio in Bangladesh was around 30 in 2010 which drastically reduced to about 14 in 2011 and also remained more or less similar in subsequent two years while the market $\mathrm{P} / \mathrm{E}$ ratio of other five Asian countries were less than 20 during 2010 to 2013.

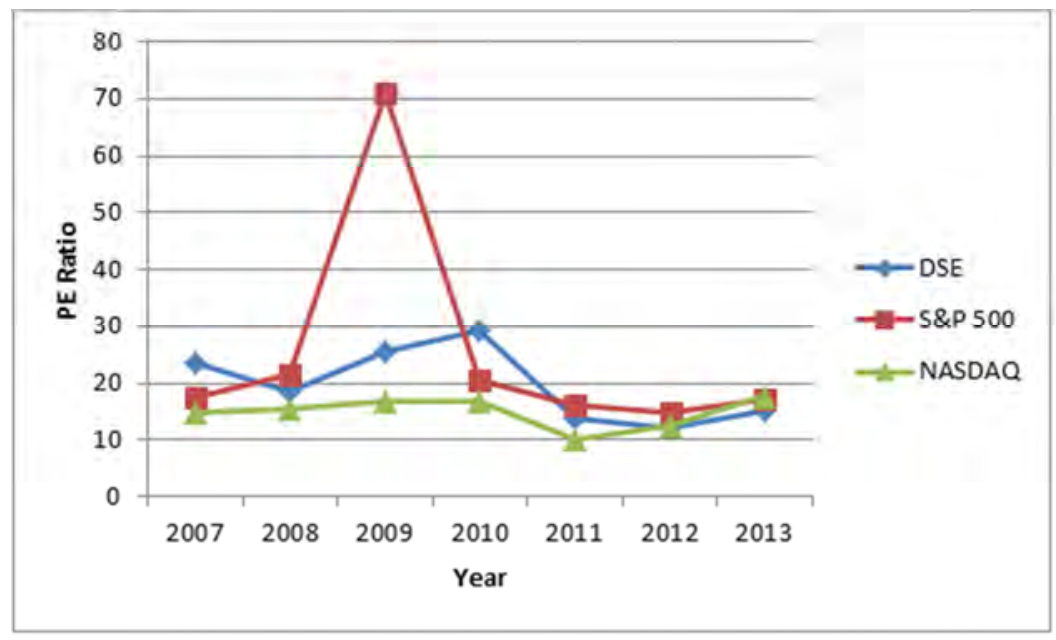

Figure 5. Comparison of DSE P/E with $S \& P$ 500, and NASDAQ.

The comparison of P/Es in Figure 5 shows that Bangladesh stock market was overvalued and reached at its peak in 2010 and after that a sharp fall was observed during 2011.

The figures, table, and related discussion in the current section confirm that Bangladesh stock market turned into a bubble during the first half of December 2010and subsequently embraced a deep crash. Although the market saw another crash in 1996, the 2010-11 crash had substantial impact in terms of the severity of its grievance, reduction of market capitalization, and the impact on investors' psychology.

\section{Explanation of Behavioral Finance Behind Bubble Burst}

According to existing economic theory, stock market bubbles subsist when the market price of stocks exceed their price determined by fundamental factors by a significant extent for an extended period [10]. The efficient market hypothesis claims that movements in stock prices are a consequence of significant changes in fundamental information such as dividend [24]. Thus, actual and fundamental prices are always the same, and bubbles cannot exist unless they are driven by irrational behavior. There are a variety of models such as Earning per share model, Cash flow per share model, and Sale per share model that can be used to calculate whether the market is overvalued. The standard finance model, which assumes that unemotional investors always force capital market prices to equal the rational present value of expected future cash flows, has considerable difficulty in explaining the dramatic growth of bubbles and their subsequent bursts. It is evident from the study of Yao and Luo [35] that even in the highly mature financial market like US, the real movements of the stock index deviated significantly from the estimated market 'fundamental value'. Therefore, there must be some other driving forces which are not captured by the traditional discount model.

Researchers in behavioral finance have, therefore, been working to enlarge the standard model with an alternative model built on two basic assumptions [5]. The first assumption is that investors are subject to sentiment, which is a belief about future cash flows and investment risks that is not justified by the facts at hand[19]. The second assumption 
is that betting against sentimental investors is costly and risky[30], [29]. The two assumptions together indicate that changes in investors' sentiment are not fully countered by arbitrageurs and so affect security returns. Shleifer and Summers [29] argue that this approach to fiancial markets is, in many ways, superior to the efficient markets model.

Authors of behavior finance, such as Shiller [28], tried to explain the stock market volatility from human psychology perspective. Some detailed explanations on market volatility and bursting bubbles in emerging markets from the perspective of human psychology are found in the researches of Akerlof and Shiller [4], Schnabl and Hoffman [26], Leijonhufvud [18], and Yao and Luo [35].

According to general financial theory, people are basically rational, well informed and unemotional in their financial decisions. However, Akerlof and Shiller [4] says that they are not always rational, well informed or unemotional, which sometime collapse the economy. Akerlof and Shiller [4] termed this irrational behavior as 'Animal Spirits'. Bubbles and their busts would not happen if all economic decisions were rational. It is the irrational animal spirits of human behavior that stir the economic waters. Akerlof and Shiller [4] integrated psychology with economics and indicated five animal spirits that influence the economic events most, which are: confidence, fairness, antisocial behavior, money illusion, and stories. Animal spirits are human emotions, which cannot be turned off. If they are not checked, they drive the economy into misbegotten bubbles and disastrous busts. Therefore, the authors propose more government regulation to mitigate the effects of irrational animal spirits on the economy.

Kahneman and Tversky [14] developed 'Prospect theory'the most often quoted as well as documented theory that explains the economic psychology of individual investors. According to the theorists "investors have an irrational tendency to be less willing to gamble with profits than with losses [14]." In particular, people prefer certainty and, therefore, overweight on the outcomes that are considered more certain than that are perceived mere probable. This is called certainty effect, which states that individuals are not always risk-averse; they tend to be risk averse in the situation of gains, or when things are going well, and relatively risk taking in the situation of losses [20]. In other words, traders tend to take subsequent risks if they have already experienced losses. By contrast, traders who have experienced profit want to avoid further risk. Thus, people respond differently, depending on whether the choices are framed in terms of gains or losses [22].

'Herding effect' is another prominent behavioral theory that explains the causes of stock market bubbles and its subsequent bursts. Herd behavior in financial market is the tendency for individual investors to follow the actions of a larger group whether rational or irrational. Stock investment decisions of individual investor can be influenced by the others' decisions such as buy, sell, choice of stock, volume of stock to trade, and length of time to hold stock[33]. Since investors' rely on collective information than private information can results in more price deviation of the securities from fundamental value, practitioners carefully consider the existence of herding in financial markets. The impacts of herding on stock price changes can influence the attributes of risk and return models [31]. As herding occurs in both rising and falling market conditions, it has significant contribution in the development of stock bubbles and their subsequent bursts [31]. Waweru et al. [33] states that herding, through driving stock trading, can create the momentum for stock trading. However, the herding effect does not work when it reaches to a certain level because the cost require to follow the herd may increase to get the increasing abnormal returns. Investors may choose herding if they believe that herding can help them getting useful and reliable information. However, the performances of financial professionals such as financial analysts or fund managers are usually evaluated by comparing the performances with their peers. In that case, low-ability professionals may follow the behavior of their high-ability peers for developing their performance [15]. According to Goodfellowa, Bohla and Gebkab [11] herding investors in the security market take their investment decisions based on the masses' decisions of buying and selling. On the contrary, informed and rational investors usually ignore following the decisions of masses, which makes the market efficient. On the other hand, herding causes a state of inefficient market, which is usually recognized by speculative bubbles. Several elements such as overconfidence, volume of investment, and so on, may influence the herding behavior of investors. Investors, if they are more confident, rely more on private information for their investment decisions and therefore, be less interested in herding. On the other hand, when the amount of investment is large, the investors are most likely to follow the others' actions to reduce their risks [11]. Moreover, the choice of herding also depends on investors' category, for example, individual investors are more likely to follow the crowds in taking investment decision than institutional investors [11].

The 'Feedback theory' proposed by Shiller [28] or the 'Momentum strategy' proposed by Caginalp, Porter and Smith [6] can be best used to explain the psychological aspect of investors. If a particular stock was believed to be undervalued, it would encourage investors to buy out of value-based sentiment and thus generate an upward trend. The soaring stock price and success of some investors may attract public attention and promote word-of-mouth enthusiasm, heightening expectations for future price increases. This process in turn increases investor demand and thus stimulates another round of price rises. If the feedback is not interrupted, the stock price could go far beyond its fundamental value and finally create a big 'speculative bubble'. However, when these momentum traders run out of cash, high prices become unsustainable and the bubble bursts ultimately. The same feedback can also produce a negative bubble where word-of-mouth pessimism drives the sales, and market observe sudden fall of prices, the downward trend continues until the market arrives at an unsustainably low level [28]. 


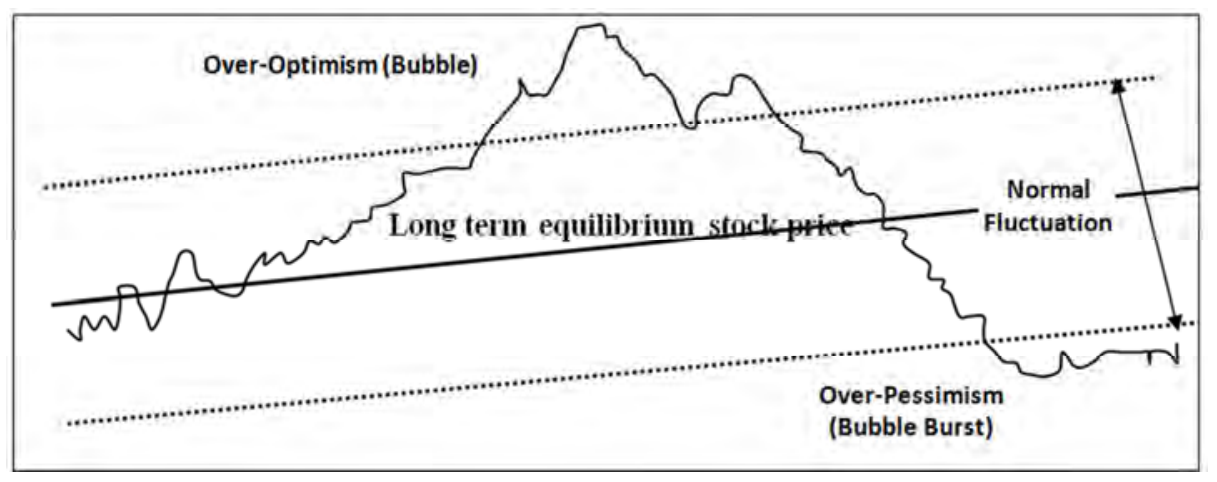

Figure 6. Normal Stock Market, Bubble, and Bubble Burst.

'Optimism' or 'overconfidence' and 'framing' have also been identified by behavioral economists as one of the reasons behind formation of bubble [28], [29]. Although speculative bubbles are easy to identify ex post, they are not realized ex ante by the majority of investors. The irrational upswing occurs because of the persistent hope of investors for a soft landing or the belief that a timely exit before the turn will be possible. In short, individual rational behavior as 'monkey see, monkey do' or the malaise of seeing the neighbor becoming rich explain the phenomenon of bubbles [26]. While Kindleberger and Aliber [17] acknowledging that a speculative mania cannot be predicted, they identify two factors that make them more likely. First, speculation is linked with positive economic expectations, particularly in new and emerging markets. Second, ample liquidity makes hyperbolic investment more likely [17]. Both factors seem relevant for the world economy since the mid of 1980s. Central banks of large industrial countries, in response to financial turmoil and the threat of recession, tend to provide ample liquidity [26].

\section{Money Making Psychologies Behind Stock Market Crash in Bangladesh}

Before the Bangladesh stock market crash in 2010-11, some market observers started sounding the alarm of a potential bubble in Bangladesh markets. Analysts cited several reasons for the 2010-11 stock market crash in Bangladesh. With consistent decline in GDP growth of Bangladesh from 6.63 percent in 2006 to the lowest fall of 5.57 percent in 2010 as shown in figure 7, the speed with which stock prices were increasing seemed disconnected from reality. Economists pointed to another reason why Bangladesh was entering into a bubble territory that the $\mathrm{P} / \mathrm{E}$ ratio on DSE unreasonably reached to around 29 in the last half of 2010, which was around 18 two years back. A study on 2006 to 2010 data incorporating 17 companies, using three valuation ratios, found that the stock market of Bangladesh was overvalued. The analysis also found a relationship between mass capital accumulation and overvalued market [1]. Many people believe that the 2010-11 stock market crash in Bangladesh was more likely to be a correction after the market's apparent overheating. There are others, however, who believe that the world financial crisis that started from the US in 2008 had a very little relation or even no relation with the Bangladesh stock market crash. However, some Bangladesh specific factors are also important to explain this stock market downturn. Somebody argue that the crash was deemed to be a scam aggravated by government failure [13]. Along with the material factors, this section describes the causes behind the development of stock market bubble in Bangladesh and its subsequent bursts during 2010-11 from psychological viewpoint of domestic investors.

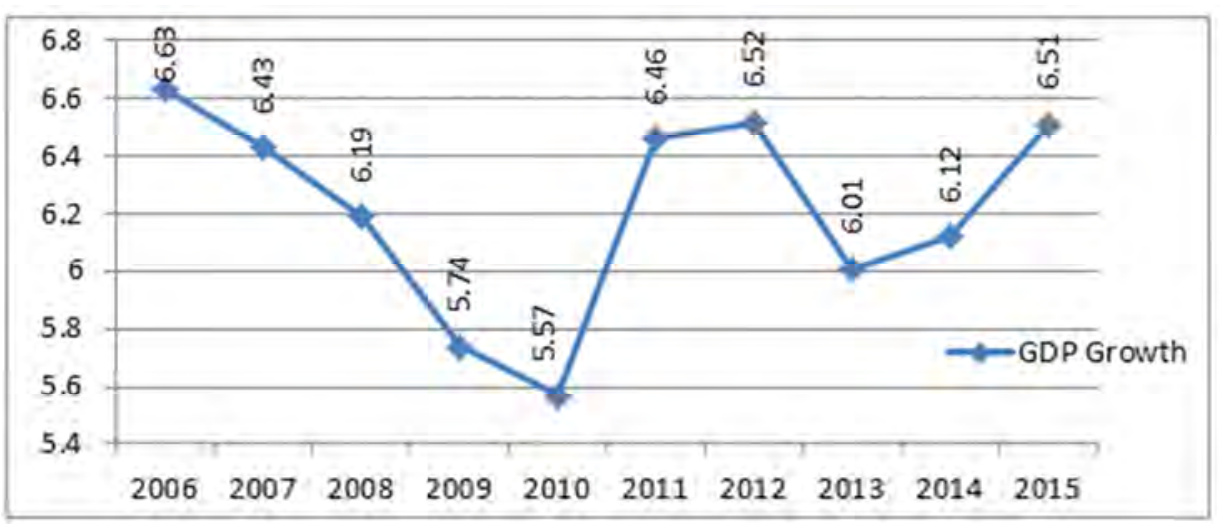

Figure 7. Trend of GDP Growth in Bangladesh during 2006-2015 (Source: Bangladesh Bank). 
Acharya and Naqvi [2] examined how banking sector contributed to the formation of asset bubbles when there was access to abundant liquidity. Excess liquidity encouraged lenders to be overaggressive and to undertake high risk with the hope that proceeds from loan growth would more than any later losses stemming from the aggressive behavior [2]. They argued that asset bubbles were more likely to be formed as a result of the excess liquidity and as such recommend that central banks should adopt a tight monetary policy in times of excessive bank liquidity. Another study has found that financial institutions in emerging markets take too much risk than that of high-income countries [18]. In an effort to isolate what influences financial institutions to take 'too much risk', the researcher found competition as one of the most influential factors. Another tendency during bull market is that when competition among financial institutions for new business is high, credit documentation and standards are relaxed. However, when the bubble bursts the risk managers often lose influence and authority to control the risk to a bearable position. For example, when 'Bank $\mathrm{X}$ ' is willing to extend a loan without a collateral agreement, at that time 'Bank Y' may reflexively choose to relax this requirement in order to maintain its competitiveness. Thus the risks of banks and the borrowers reach to a level which is higher to a significant extent than the risk bankers and traders can bear. The same case happened in Bangladesh before and after the bubble burst. Private commercial banks, giving less emphasis on their routine banking activities and exceeding the stock market exposure limit, invested heavily in stocks of other companies. When the situation was uncovered during the stock market turmoil, Bangladesh Bank imposed a timeframe to reduce the exposure to stock market that also increased the sale pressure of stocks, which ultimately fostered the decline of market.

One of the basic functions of the stock market is the efficient allocation of fund to its most productive uses [10]. Empirical evidence supports the assumption that stock market bubble can lead to overinvestment in the bubble sector [7]. Evanoff et al. [10] has found that Central banks have tended to follow an approach to asset bubble management where there is little or no restrictive monetary policy action during the bubbles' formation and growth, but there is a prompt easing in the form of quick reductions in market interest rates once the bubbles bursts. Somewhat, similar case happened in Bangladesh when the bubble burst occurred during 2010-11, Bangladesh Bank, the central bank of Bangladesh, relaxed many of its restrictions but it did not work due to severe frustration among the investors.

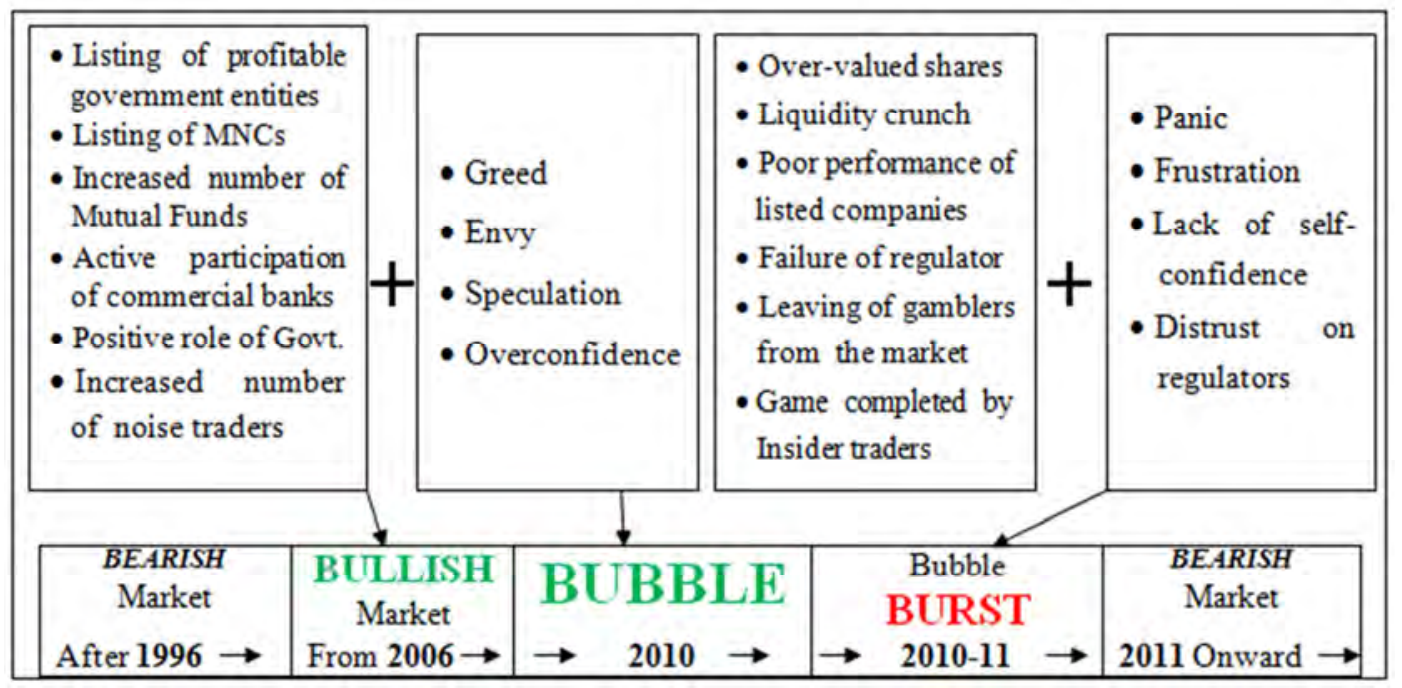

Figure 8. Moneymaking psychologies along with other factors behind the development and burst of stock bubble in Bangladesh.

Although existing studies on behavioral finance provide some useful discourse on why bubbles develop in stock markets and why these bubbles burst, the stunning bubble and burst of the Bangladesh stock market cannot be fully explained by established theories. The most important explanation for Bangladesh stock market bubble is the specific moneymaking psychologies of domestic investors. The specific psychologies can be best described by four key words: 'greed', 'envy', 'speculation', and 'overconfidence' as shown in figure 8.

'Greed' results in when investors want to become rich very quickly. Due to economic growth supported by Readymade Garments (RMG) sector along with some other factors, many people fortunately became rich within a very short span of time. In the meantime, a restless and greedy culture had emerged in the country. For people who had not been able to become rich, the share markets provided a unique opportunity. Thanks to the bullishness of the markets after 2006 to 2009 , many investors earned hefty paper profits. To increase their gains further, many investors did not hesitate to pump more cash into shares. They were not prepared to simply sell the shares to cash the profits that had already been made. Their eagerness to pour more cash into the market and their refusal to take profits were two important symptoms of greediness. Such behavior led to the huge market bubble which saw the overall market $\mathrm{P} / \mathrm{E}$ ratio to 30 
in 2010 when the market $\mathrm{P} / \mathrm{E}$ ratios of some Asian countries were typically around 15 . The dramatic increase in the share prices of different IPOs on its first day of trading on DSE can be considered good example of greed.

'Envy' drove many investors, irrespective of their age, gender, and profession, to take part in the stock markets for fear of missing a unique opportunity to make 'easy money' [34]. By November 2009, 3.3 million trading accounts registered with DSE and CSE suggest that one in 45Bangladeshi was directly involved in stock trading and many more indirectly. However, their lack of professional knowledge made their investments highly speculative. Being influenced by the 'herding effect', they either purchased shares randomly or followed others without analyzing the performance of the companies by themselves. In order to catch up with index fluctuations, huge amounts of money streamed from banks to stock markets during the bullish period, and vice versa occurred during the bearish period. Such fund transfers significantly increased market volatility. In the US, it took more than five years for the Dow Jones Industrial Index to reach its peak of 14,279.96 on 11 October 2007; in China, it took less than 18 months for the SSE Composite Index to rise to its highest level of $6,124.04$ on 16 October 2007; whereas in Bangladesh, it took less than one year to reach to the highest peak at 8,918 point. On January 3, 2010, DSE's General Index was at 4568.40, which went up by a stunning 4,350 points- a 95.23 per cent increase on December 05, 2010. On January 10,2011 , trading on the DSE was halted after it fell by 660 points, or 9.25 per cent, in less than an hour- the biggest one-day fall in the history of 55 years of the bourse. The CSE also met the same fate during the turmoil. Facing sudden transformations, investors had no time to respond and protect themselves adequately, incurring massive loss. Many investors had fallen victim to their 'envy', and had become extremely vulnerable to market abuses and other deliberate acts of major market players.

'Speculation' occurred as a result of the relatively few investment opportunities available to investors in Bangladesh. In most of the developed countries by contrast, various financial instruments, such as bank savings, corporate securities, and insurance services are readily available to all investors. Instead of investing in a single product, people usually prefer to maintain a mixed portfolio and want to get a long-term stable return from their investments [34]. In Bangladesh, however, bank savings were the only way to invest for general people. However, bank deposits tended to earn negative real interests due to a very high inflation rate. Therefore, when stock markets revived abruptly, presenting some opportunities to gain profits, people rushed to withdraw money from banks to invest in stocks on the hope of making positive returns on their savings. During the bullish period, they pooled all their available funds, which not only included their own savings deposits of the retail investors, but also the deposits of their parents and relatives, to trade in stocks. When the markets turned bearish, few investors however wanted to exit immediately. In contrast, many investors preferred to hold onto their shares and hope for further gains. Therefore, as the situation deteriorated, the value of their shares shrank even further and an irreversible downturn resulted across the entire market.

'Overconfidence' is another psychological state of mind that generates disagreements among investors regarding fundamental prices of stocks, usually above fundamental, which results in excessive trading and excess volatility [25]. With short-sale constraint, an owner of stocks has an option to sell the stocks to other overconfident investors who have more optimistic beliefs. This re-sale option has a recursive structure, that is, a buyer of the asset gets the option to resell it. The re-sale opportunity creates a significant bubble in stock prices when small variations of beliefs are sufficient for a trade. Investors pay prices that exceed their own valuation of future dividends because of their belief that they will find a buyer willing to pay even more in near future. The most overconfidence of investors forms "overconfident markets", and the least overconfidence of investors form "rational markets'. Prices in rational markets follow the fundamental asset value more accurately than prices in overconfident markets and are significantly lower and less volatile [21]. Furthermore, significant higher bubble measures as well as very high trading volume are observed in overconfident markets. Data from Bangladesh stock market provide evidence that overconfidence had strong effects on prices and trading behavior during the formation of bubble.

The most important explanation for the burst of stock market bubble in Bangladesh was overvaluation of listed companies. Because of 'Harding effect' along with other psychological factors, when the $\mathrm{P} / \mathrm{E}$ ratio of many established western companies was around 10 to 15 , it increased to 30 during 2010 in Bangladesh. This suggests that even if the performances of Bangladeshi companies were as good as their western counterparts, share prices of Bangladeshi listed companies had been overvalued. Therefore, when the market plunged, the value of stocks evaporated just like a water bubble. Consequently, ignorant investors had to endure massive losses.

Finally, as the stock market bubble was largely inflated by 'greed', 'envy', 'speculation', and 'overconfidence' the current bearish market represents not only a market correction but also a depression caused by the psychological factors of 'panic', 'frustration, 'lack of self-confidence' and 'distrust on regulator'. These psychological factors underpin the difficulty of a quick market recovery even if current share prices are lower than the 'true' market values of listed companies. This means that it will take a rather long time for the market to become bullish again.

\section{Conclusion}

Based on the current study and the existing theories a number of key observations have been made about stock market crush in Bangladesh during 2010-11. First, evidence suggests that development of stock market bubbles and their 
bursting are not unpredictable events; they occur relatively frequently and some are more damaging to the overall economy. Comparing the harsh effects of stock market bubble bursts, the existing stock of knowledge in the related field has been found insufficient in Bangladesh. Many individual investors still do not know how to identify bubbles, what really causes them to grow and burst, and what their implications are. Therefore, more researches need to be carried out to address these questions. Second, the capital market crush in Bangladesh has created a consensus that government policies and regulations are not sufficient to achieve market stability. Thus, existing policies should be reevaluated and alternative policies need to be developed to address potential development of bubbles and their bursts. Third, investors in Bangladesh capital market should not forget the proverb "if it looks like a duck, swims like a duck, and quacks like a duck, then it probably is a duck." They should ignore the voices that may tempt them to believe that "this time is different" or that "we have learned our lesson in 1996 or 2010-11, so it cannot happen again" and to take irrational decision related to buy or sale of securities. Fourth, since psychological factors have been identified as one of the influential factors behind development and burst of bubbles, it is recommend to the government of Bangladesh and the regulators to initiate psychological training sessions, along with many training programs, for investors so that they behave rationally. Finally, to build a mature stock market in Bangladesh as a long term and secure place for investors, Bangladeshi investors should take more training about ways to control 'greed', 'envy', 'speculation', and 'overconfidence' and the government should learns how to prevent key market players from abusing their market power. In the long run, if most Bangladeshi investors can be made more aware of the potential risks and returns, the stock markets will be less volatile and will be able to avoid any further dramatic creation of bubble and subsequent burst, which ultimately will turn Bangladesh stock market into a more reliable place for investments. The regulator, through ensuring free flow of authentic information and ensuring corporate governance, can play an important role in this process.

\section{References}

[1] Abdullah, M. N., Parvez, K., \& Khaled, M. (2012). Is the stock market overvalued: A study in the context of Bangladesh? Asian Business Review, 1 (1), 30-36.

[2] Acharya, V., \& Naqvi, H. (2011). Bank liquidity and bubbles: Why central banks should lean against liquidity. Bubbles and Macroprudential Regulation (April 2011). Loyola University.

[3] Ahmed, G. T. (2013, April). Market PE hits nine-year low. The Daily Star.

[4] Akerlof, G. A., \& Shiller, R. J. (2009). Animal Spirits: How Human Psychology Drives the Economy, and Why It Matters for Global Capitalism. Princeton and Oxford: Princeton
University Press.

[5] Baker, M., \& Wurgler, J. (2007). Investor sentiment in the stock market. Journal of Economic Perspectives, 21 (2), 129-151.

[6] Caginalp, G., Porter, D., \& Smith, V. (2001). Financial bubbles: Excess cash, momentum, and incomplete information. Journal of Psychology and Financial Markets, 2 (2), 80-99.

[7] Chirinko, R. S., \& Schaller, H. (2001). Business fixed investment and "bubbles": The Japanese case. American Economic Review, 91 (3), 663-680.

[8] Choudhury, M. A. (2013). Stock market crash in 2010: An empirical study on retail investor's perception in Bangladesh. ASA University Review, 7 (107-21).

[9] Estrada, J. (2005). Adjusting P/E ratios by growth and risk: The PERG ratio. International Journal of Managerial Finance, 1 (3), 187-203.

[10] Evanoff, D. D., Kaufman, G. G., \& Malliaris, A. G. (2012). Asset price bubbles: What are the causes, consequences, and public policy options? Chicago: The Federal Reserve Bank.

[11] Goodfellowa, C., Bohla, M. T., \& Gebkab, B. (2009). Together we invest? Individual and institutional investors' trading behaviour in Poland. International Review of Financial Analysis, 18 (4), 212-221.

[12] Huang, J. Y., Shieh, J. C., \& Kao, Y.-C. (2016). Starting points for a new researcher in behavioral finance. International Journal of Managerial Finance, 12 (1), 92 - 103.

[13] Jewel, M. N. (2012, October Tuesday). Share market crash and the reasons behind the disaster. The Financial Express, 20 (157).

[14] Kahneman, D., \& Tversky, A. (1979). Prospect theory: An analysis of decision-making under risk. Econometrica, 47 (2), 263-291.

[15] Kallinterakis, V., Munir, N., \& Radovic-Markovic, M. (2010). Herd behavior, llliquidity, and extreme market states: Evidence from Banja Luka. Journal of Emerging Market Finance, 9 (3), 305-324.

[16] Khaled, K. I. (2011). Share market inquiry committee, 2011. Dhaka: Ministry of Finance, The Peoples' Republic of Bangladesh.

[17] Kindleberger, C. P., \& Aliber, R. Z. (2005). Manias, panics, and crashes: A history of financial crises (5th Edition ed.). Hoboken, NJ: John Wiley \& Sons.

[18] Leijonhufvud, C. (2007). Financial globalisation and emerging markets volatility. The World Economy, 30 (12), 1817-42.

[19] Long, J. B., Shleifer, A., Summers, L. H., \& Waldmann, R. J. (1990). Noise trader risk in financial markets. The Journal of Political Economy, 98 (4), 703-738.

[20] McDermott, R. (1998). Risk-taking in international politics: prospect theory in American foreign policy. Michigan: The University of Michigan Press.

[21] Michailova, J., \& Schmidt, U. (2016). Overconfidence and bubbles in experimental asset markets. Journal of Behavioral Finance, 17 (3), 280-92.

[22] Ngoc, L. T. (2014). Behavior pattern of individual investors in stock market. International Journal of Business and Management, 9 (1), 1-16. 
[23] Rahman, M. T., \& Moazzem, K. G. (2011). Capital Market of Bangladesh: Volatility in the Dhaka Stock Exchange (DSE) and Role of Regulators. International Journal of Business and Management, 6 (7), 86-93.

[24] Rappoport, P., \& White, E. N. (1993). Was there a bubble in the 1929 stock market? The Journal of Economic History, 53 (3), 549-574.

[25] Scheinkman, J. A., \& Xiong, W. (2003). Overconfidence and speculative bubbles. Journal of Political Economy, 111 (6), 11831219.

[26] Schnabl, G., \& Hoffmann, A. (2008). Monetary policy, vagabonding liquidity and bursting bubbles in new and emerging markets: An overinvestment view. The World Economy, 12261252.

[27] Shefrin, H. (2006). Beyond greed and fear: Understanding behavioral finance and the psychology of investing. Oxford University Press.

[28] Shiller, R. J. (2003). From Efficient Market Theory to Behavioral Finance. Journal of Economic Perspective, 17 (1), 83-104.

[29] Shleifer, A., \& Summers, L. H. (1990). The noise trader approach to finance. Journal of Economic Perspective, 4 (2), 19-33.
[30] Shleifer, A., \& Vishny, R. W. (1997). The limits of arbitrage. The Journal of Finance, 52 (1), 35-55.

[31] Tana, L., Chiangb, T. C., Masonb, J. R., \& Nelling, E. (2008). Herding behavior in Chinese stock markets: An examination of A and B shares. Pacific-Basin Finance Journal, 16 (1-2), 61-77.

[32] Waweru, N. M., Munyoki, E., \& Uliana, E. (2008). The effects of behavioural factors in investment decision-making: A survey of institutional investors operating at the Nairobi Stock Exchange. International Journal of Business and Emerging Markets, 1 (1), 24-41.

[33] University of Florida. (2014). What are the characteristics of an economic bubble? Retrieved March 20, 2017, from www2.mae.ufl.edu/ uhk/BUBBLECHARACTERISTICS.pdf

[34] Yao, S., \& Luo, D. (2008). Chinise stockmarket bubble: Inevitable or incidental?

[35] Yao, S., \& Luo, D. (2009). The economic psychology of stock market bubbles in China. The World Economy, 667-691. 